\title{
Accelerating the Social Media Process: The Impact of Internet Celebrity Word-of-Mouth Communication and Relationship Quality on Consumer Information Sharing
}

\author{
Liping Liu (Corresponding author) \\ International College, National Institute of Development Administration \\ PO Box 10240, Bangkok, Thailand \\ E-mail: $865248131 @$ qq.com \\ Chih-Cheng Fang \\ International College, National Institute of Development Administration \\ PO Box 10240, Bangkok, Thailand \\ E-mail: francis.fang@gmail.com
}

Received: Dec. 15, 2019 Accepted: Jan. 12, 2020 Online published: Jan. 15, 2020

doi:10.5296/ijhrs.v10i1.16043ＵRL: https://doi.org/10.5296/ijhrs.v10i1.16043

\begin{abstract}
With the rapid development of "Internet plus", the number of Internet users in China has increased rapidly, and the number of active users of social media software ranks first in the world. Large Numbers of network users are also potential consumer groups. Social media influences other consumers through consumer interaction and social interaction, and consumers are transformed into active information acquisition rather than passive information reception. Word of mouth marketing on social media has become one of the hottest research fields. Based on the information adoption model, this study explores the impact of internet celebrity word-of-mouth communication on consumer information sharing from four dimensions: internet celebrity word-of-mouth communication, relationship quality, face consciousness, and consumer information sharing and establishes a research model to provide references and suggestions for subsequent researchers and enterprise management.
\end{abstract}

Keywords: internet celebrity word-of-mouth communication, relationship quality, face consciousness, consumer information sharing 


\section{Introduction}

China's huge amount of active users, such as Tencent WeChat number of monthly active users reached 1 billion, Weibo active users more than 340 million a month, far more than the number of any other country(Chu, Windels, \& Kamal, 2016), With the rise of a new generation of consumers who are more proficient and frequent users of social media, the communication, and interaction between people, communities and organizations have also changed (Dehghani \& Tumer, 2015; Ngai, Tao, \& Moon, 2015). People create share and exchange information in virtual communities (M. N. Hajli, 2014c; N. Kim \& Kim, 2018). Social media influences other consumers through consumer interaction and social interaction, and consumers are transformed into active information acquisition rather than passive information reception (Ahmad \& Laroche, 2017).

The research on the value of Internet word of mouth derived from social media is becoming an important field of interest for scholars and practitioners in various fields. Internet word of mouth has affected every aspect of people's life, including social, business, education and political aspects (Alalwan, Dwivedi, Rana, \& Williams, 2016; Algharabat, Alalwan, Rana, \& Dwivedi, 2017; Boulianne, 2015; Zeng \& Gerritsen, 2014). Similarly, it also brings new challenges to enterprises. The influence of internet celebrity word of mouth and consumer information means huge market value for enterprises (Muralidharan, Rejón-Guardia, \& Xue, 2016; Swani, Milne, Brown, Assaf, \& Donthu, 2017).

This study focuses on word-of-mouth communication on social media. Firstly, previous studies on internet celebrity word-of-mouth communication focused on its impact on consumer decision-making (Cooley \& Parks-Yancy, 2019; Djafarova \& Trofimenko, 2019; Goodrich \& De Mooij, 2014), impact on information usefulness (Davis, 1989; Hamid, Razak, Bakar, \& Abdullah, 2016), impact on consumer behavior (Hennig-Thurau, Wiertz, \& Feldhaus, 2015; Sari \& Yulianti, 2019). Secondly, there are also studies that regard consumer word-of-mouth communication as a process of word-of-mouth re-dissemination. The existing literature only focuses on consumer information sharing from the perspective of consumer attitude (Park, Gu, Leung, \& Konana, 2014), information content characteristics (Hur, Kim, Karatepe, \& Lee, 2017), consumer perceived value (Changliang, Xiwei, \& Chenxiao, 2019). However, in the above studies, internet celebrity's word-of-mouth dimension was not subdivided, nor was there any empirical study to transfer the research perspective from individual consumers to the correlation between consumers, and it was proposed to take internet celebrity word-of-mouth communication as the initial communication and consumer information sharing as the re-transmission. In view of this, this study internet celebrity information source and information quality two aspects to study internet celebrity spread by word of mouth, and from its basic concept, structure dimension, the related research of internet celebrity of the spread of word-of-mouth elaborates the theoretical framework, expect to further supplement and extension internet celebrity word-of-mouth communication research, has theoretical significance to the rich internet celebrity spread by word of mouth.

Furthermore, cultural background influences consumers' consumption values, beliefs, attitudes and lifestyles (Saleem, 2017), Face consciousness plays an important role in the 
Confucian society (Han, 2016). In the context of Confucian culture, face consciousness has become one of the important factors that influence consumer behavior (James, Hu, \& Leonce, 2019). Under the background of collectivism, Chinese consumers tend to follow the choices of the majority, so they are more susceptible to the influence of internet celebrity word-of-mouth communication. This study introduces the self-presentation theory, which explains that Face consciousness, as a cultural factor, plays a moderating role in consumers' information sharing in the face of the target audience of social media based on consumers' own motivation and self-efficacy.

In conclusion, this study established a theoretical model based on the information adoption model that internet celebrity word-of-mouth communication affects consumers' information sharing through the relationship quality and the adjustment of face consciousness.

\section{Literature Review}

\subsection{Theoretical Basis}

Information Adoption Model (IAM) is based on Davis's (1989)'s Technology Acceptance Model (TAM) and Petty, Cacioppo, and Petty, Cacioppo, and Goldman (1981)' s Elaboration Likelihood Model (ELM). Information Adoption Model (IAM) uses information source credibility, information quality, and perceived usefulness to predict information adoption behavior (Sussman \& Siegal, 2003).

(1) Information quality is the persuasiveness of information, which is defined as the degree of satisfaction that information can bring to users and the applicability that can be perceived by users (Laumer, Maier, \& Weitzel, 2017). Information quality is divided into four dimensions: comprehensiveness, relevance, accuracy, and timeliness (Bailey \& Pearson, 1983).

(2) Source credibility is defined as the degree to which the information source is considered competent and trustworthy by the information receiver. Source credibility is divided into source professionalism and source reliability (Cheung, Lee, \& Rabjohn, 2008).

(3) Perceived usefulness is the precondition of information adoption, the degree to which information receivers enhance or improve their perceived performance is defined as the extent to which people make online decisions by seeking and adopting the opinions and comments of other online users, which affects users' willingness to use (Pitta \& Fowler, 2005). Social internet celebrity word-of-mouth dissemination of business environment, perceived usefulness can bring beneficial and valuable content to information receivers, which can improve the economy, knowledge, and mood of information receivers. In this study, the perceived usefulness is represented by relationship quality. Consumer satisfaction, consumer trust and consumer commitment in the relationship quality are all consumers' true feelings towards internet celebrity word-of-mouth communication, which are also regarded as a further emotional enhancement of consumers' perceived usefulness. In the word-of-mouth communication of internet celebrities, consumers reach a certain recognition or consensus on the value conveyed by the information, thus forming their own value positioning.

(4) Information adoption is the degree to which consumers adopt information and the 
behavior of individuals or organizations in adopting technologies based on social psychology and behavioral science (Bhattacherjee, Perols, \& Sanford, 2008; Davis, 1989).

In addition, there are two ways to influence information reception in IAM, the central route and the marginal route (Shen, Cheung, \& Lee, 2013; Tien, Rivas, \& Liao, 2019). The central route refers to the core of the message, while the marginal route refers to the issues indirectly related to the core of the message (Cheung et al., 2008; Shu \& Scott, 2014). The quality of information is regarded as the central route, while the source credibility is the marginal route. Both promote the adoption of information through perceived usefulness. Thus, IAM can explain how people are affected by information dissemination on social media platforms. In addition, in internet celebrity word-of-mouth communication under the social business environment, information adoption refers to the attitude or intention of information receivers to accept certain types of information, while consumer information sharing refers to the result of consumers' adoption of the information they receive.

\subsection{Research Hypothesis}

\subsubsection{Information Quality and Relationship Quality}

(1) Visual cue

Visual Cues are the incentive of Visual perception. In social media platforms, Visual Cues can often bring intuitive impressions and emotions to consumers. The information conveyed through Visual Cues of online word-of-mouth can form product expectations and help consumers make decisions (Simmonds \& Spence, 2017).

The service landscape of a casino can affect customer satisfaction (Lam, Chan, Fong, \& Lo, 2011). Studies of restaurants have also found that appealing interior design is an important factor in improving customer satisfaction (Namkung \& Jang, 2008). Similarly, the music and color of a bar can affect customer satisfaction (Lin, 2009). Therefore, it can be considered that the visual cues of service sites will affect consumer satisfaction.

The following assumptions are made in this study:

H1-1a: Visual cues will have a positive effect on consumer satisfaction

H1-1b: Visual cues will have a positive effect on consumer trust

H1-1c: Visual cues will have a positive effect on consumer commitment

(2) Timeliness

Timeliness refers to the latest trends and developments in the product field reflected by the recommendation information, as well as the degree of real-time update of the information (S.-E. Kim, Lee, Shin, \& Yang, 2017). The value and usefulness of information are often reflected in the timeliness of information, that is, the timeliness of the information. When the timeliness expires, the effect of information will be greatly reduced (Djafarova \& Rushworth, 2017).

Internet celebrity tends to adopt the latest products, so the product recommendation 
information of internet celebrity is often time-efficient, which can recommend and introduce new products to consumers at the early stage of product diffusion and exert formal and informal influence through various communication channels, ultimately influencing people's choices (Mohammadi, Saraee, \& Mirzaei, 2015).

A study of airasia's service quality by university students at University Utara Malaysia found a significant positive correlation between timeliness of the information and customer satisfaction (Abu Bakar, Zulkafly, Rashad, Hanafie, \& Melan, 2017). In addition, in the study on the service quality of online shopping third-party logistics, the timeliness of logistics information refers to the timeliness, convenience, and sufficiency of information, including information used for goods tracking and information update. The richer the logistics information, the more satisfied the customers will be. The results of the principal component analysis showed that the timeliness of information was the influencing factor of high satisfaction (H. Chen \& Qi, 2016). The quality of e-word-of-mouth information, which is characterized by timeliness, accuracy and information content has an impact on the perceived trust of e-word-of-mouth (S. Lee \& Choeh, 2018). More research shows that customer satisfaction (Iglesias, Markovic, \& Rialp, 2019)、 trust (Tabrani, Amin, \& Nizam, 2018) is an important factor of commitment (Lee \& Wong, 2016).

The following assumptions are made in this study:

H1-2a: Timeliness will have a positive impact on consumer satisfaction

H1-2b: Timeliness will have a positive impact on consumer trust

H1-2c: Timeliness will have a positive impact on consumer commitment

\section{(3) Recommendation consistency}

Recommendation consistency refers to the degree of consistency between the current recommendation of an internet celebrity and the experience of other internet celebrities evaluating the same product or service in a specific domain (Hussain et al., 2018). Based on the similarity attraction effect, consumers tend to buy goods or look up information from similar rather than different sources (Balabanis \& Chatzopoulou, 2019). Recommendation consistency reflects the degree to which the current recommendation is consistent with the experience of other individuals evaluating the same product or service. When there is good consistency between multiple recommendations, people will think that this is a recommendation with high credibility (J. Chen, Teng, Yu, \& Yu, 2016).

Recommendation quality has a significant positive impact on customer satisfaction (Roudposhti et al., 2018). Because cognitive trust comes from accumulated knowledge and is based on performance-related attributes, an official account that consistently promotes high-quality articles can build strong cognitive trust among its readers (Y. Chen, Lu, Wang, \& Pan, 2019). Secondly, the study on the effect of online recommendation based on e-word-of-mouth on trust found that women trusted e-word-of-mouth emails more than men. However, both sexes rated the mixed positive and negative e-word-of-mouth as more trustworthy than the full positive or negative e-word-of-mouth (Prendergast, Paliwal, \& Chan, 
2018). Based on the relationship among satisfaction, trust and commitment, customer satisfaction (Iglesias et al., 2019; Rather \& Sharma, 2017), trust (Tabrani et al., 2018) is an important factor of commitment (Lee \& Wong, 2016).

The following assumptions are made in this study:

H1-3a: Recommendation consistency will have a positive impact on consumer satisfaction

H1-3b: Recommendation consistency will have a positive impact on consumer trust

H1-3c: Recommend consistency will have positive effects on consumer commitment

\subsubsection{Source Credibility and Relationship Quality}

Professional knowledge, product involvement, interactivity, and popularity are considered source credibility, while visual cues, timeliness, and consistency of recommendations are considered information characteristics. Source credibility and information characteristics have positive and significant effects on perceived usefulness and perceived usability respectively, while perceived usability and perceived usefulness have positive and significant effects on trust respectively (J.-W. Kang \& Namkung, 2019).

(1) Professional knowledge

The specialization of internet celebrity word-of-mouth communication is closer to product knowledge. The specialization of internet celebrity should include not only product knowledge in the field, but also relevant product experience and experience (Teng, Khong, Chong, \& Lin, 2017). The professionalism of internet celebrity has a significant positive impact on consumer trust (Wei \& Meng, 2016).

People search for information online and consider other consumer reviews of products or services before making a purchase decision. For example, if someone wants to eat, he or she can consider information about different restaurants and other customer reviews before deciding (Yan, Wang, \& Chau, 2015). Online e-word-of-mouth has a significant positive impact on consumer satisfaction (Nagy, Kemény, Szücs, Simon, \& Kiss, 2017). Research on smartphone purchases by young people in India also shows that opinion leaders have a significant positive impact on consumer satisfaction (Rajput \& Talan, 2017). E-word-of-mouth can influence the continued use of social commerce through consumer trust and consumer commitment, respectively (Noori, Hashim, \& Yusof, 2016).

The following assumptions are made in this study:

H2-1a: Internet celebrity professionalism will have a positive impact on consumer satisfaction

H2-1b: Internet celebrity professionalism will have a positive impact on consumer trust

H2-1c: Internet celebrity professionalism will have a positive impact on consumer commitment 
(2) Product involvement

When consumers realize that a product is important to them, they are in a state of high involvement, which drives them to actively seek information about the product to make decisions that best meet their needs. This is exactly the performance of internet celebrity in the field of interest, reflecting internet celebrity's concern and preference for products (Goldsmith, Flynn, \& Goldsmith, 2003). Product involvement of internet celebrity has a significant positive impact on consumer trust (Wei \& Meng, 2016). In addition, travel is a product purchased by tourists, and travel involvement has a significant positive impact on the destination experience (Ferns \& Walls, 2012). Based on the research of Vietnamese people using smartphones, it is found that there is a positive correlation between brand experience and brand loyalty, and brand trust and brand satisfaction positively affect brand loyalty (Nguyen \& Tran, 2018). Based on the empirical study on the relationship among trust, loyalty, commitment, and satisfaction of Portuguese customers in the distribution industry, trust has a positive effect on commitment, trust has a positive effect on satisfaction, commitment has a positive effect on loyalty, and satisfaction has a positive effect on loyalty (Bricci, Fragata, \& Antunes, 2016).

The following assumptions are made in this study:

H2-2a: Internet celebrity product involvement will have a positive impact on consumer satisfaction

H2-2b: Internet celebrity product involvement will have a positive impact on consumer trust

H2-2c: Internet celebrity product involvement will have a positive impact on consumer commitment

\section{(3) Interactivity}

The interaction of internet celebrity has a significant positive effect on consumer trust (Wei \& Meng, 2016). Consumers may be affected by internet celebrity. Internet celebrities will share information and communicate with them online. Social interaction has important information and normative influence on consumer trust (Kollat \& Farache, 2017).

Salespeople's use of social media can affect customer satisfaction because the message is important to the customer (Agnihotri, Dingus, Hu, \& Krush, 2016). Research results based on network learning show that interactivity has a significant positive effect on satisfaction (Horzum, 2015). While teachers and internet celebrities are message senders, students and fans are message receivers. Learner satisfaction is positively correlated with teacher-student interaction (Cho \& Kim, 2017). Customer satisfaction (Su, Swanson, Chinchanachokchai, Hsu, \& Chen, 2016), customer trust (Bricci et al., 2016) Positive impact on customer commitment.

The following assumptions are made in this study:

H2-3a: Internet celebrity interactivity will have a positive impact on consumer satisfaction

H2-3b: Internet celebrity interactivity will have a positive impact on consumer trust 
H2-3c: Internet celebrity interactivity will have a positive impact on consumer commitment

(4) Fame

A study of brands and endorsers in India's telecoms industry suggests that celebrity credibility has a positive impact on brand trust and relationship commitment (Dwivedi \& Johnson, 2013). In addition, in developing countries, the professional level, intention and popularity of the sales staff and other attributes will affect customer trust in the sales staff (Andaleeb \& Anwar, 1996). Athletes use their popularity in social media software such as Twitter to turn it into considerable income based on fan trust, which represents a unique marketing resource and communication channel for star athlete products, and fan trust is the basis of their conversion (Hambrick \& Mahoney, 2011). The reputation of e-tailers can have an impact on consumers' initial trust (Sebastianelli \& Tamimi, 2018).

In addition, a study on the purchase intention of students at the University of Cape Coast, Ghana, found that there was a significant positive correlation between customer satisfaction and celebrity characteristics, and celebrity characteristics affected customers' purchase intention completely through satisfaction (Domfeh, Kusi, Nyarku, \& Ofori, 2018).

The following assumptions are made in this study:

H2-4a: Internet celebrity visibility will have a positive impact on consumer satisfaction

$\mathrm{H} 2-4 \mathrm{~b}$ : Internet celebrity visibility will have a positive impact on consumer trust

H2-4c: Internet celebrity visibility will have a positive impact on consumer commitment

\subsubsection{Relationship Quality and Consumer Information Sharing}

In the word-of-mouth communication of internet celebrity, consumers reach a certain recognition or consensus on the value conveyed by the information, thus forming their own value positioning. The information released by the information source will arouse the emotional resonance of consumers and generate relationship quality. In the model of the limited ability of information processing, the information in internet celebrity's word-of-mouth communication tends to have a strong emotional color. The more information that can arouse users' emotional resonance, such as information that makes users feel happy, interesting or even angry, the more can increase the useful and sexy effect of users and meet their psychological needs. Internet celebrity word-of-mouth communication that consumers pay attention to can meet the needs of its products or services, make users contact with more new things, and enrich the user's knowledge. Consumers comment on, forward, and share relationships based on their quality.

Social media enriches relationships by building strong relationships with consumers (M. N. Hajli, 2014b). At the same time, specific to social media platforms, many enterprises use social media information release platforms to establish close interaction with customers (M. N. Hajli, 2014c). Consumer information sharing affects the quality of relationships and decisions between business partners (M. N. Hajli, 2014a). Relationship quality refers to the ability of online retailers to reduce consumers' perception of uncertainty. Through social 
media and internet celebrity word-of-mouth communication, consumers can interact with internet celebrity groups and observe their daily information release, thus establishing a highly interactive environment between the two (J. Kang, Tang, \& Fiore, 2014). In social media, information sharing is regarded as the expression of the interaction between two parties, which is closely related to the quality of the relationship. Consumers are aware of the potential impact of information sharing on their interpersonal relationships. According to attachment theory, personal attachment can directly affect consumers' satisfaction, commitment, and involvement in shopping. Consumer attachment has a direct influence on satisfaction and trust (Belaid \& Temessek Behi, 2011). Through the interaction of social media, consumers can generate the psychology of satisfaction, trust, and commitment (Casaló, Flavián, \& Guinalíu, 2007).

Previous studies have studied the relationship between social media and social commerce from the perspective of behavior based on users' trust and willingness to use social commerce. In other words, based on the reciprocal relationship between social network users and how much others care about users, their recommendation intentions will be affected (N. Hajli \& Sims, 2015). In addition, from the perspective of social existence, the internet celebrity group's presence on social media increases consumers' trust in it, thus changing consumers' recommendation intentions in social media.

Based on the above discussion and combining hypothesis 1-1a to hypothesis 2-4c, the following hypotheses are proposed in this study:

H3a: Consumer satisfaction will have a positive impact on consumer information sharing

H3b: Consumer trust will have a positive impact on consumer information sharing

H3c: Consumer commitment will have a positive impact on consumer information sharing

\subsubsection{The Moderating Effect of Face Consciousness}

Face consciousness has become an important factor influencing consumer behavior (Bao et al, 2003). Face consciousness is a phenomenon existing in different cultures. Compared with western consumers, southeast Asian consumers pay more attention to face consciousness and it is more obvious in Chinese culture (J. Li, Zhang, \& Sun, 2015; L. Wang, Wei, \& Zhang, 2018). As a prominent factor, culture plays a regulating role in consumer decision-making (Ng, 2013; Pentina, Zhang, \& Basmanova, 2013; J.-C. Wang \& Chang, 2013; K. Z. Zhang \& Benyoucef, 2016). The use of social business under different cultural backgrounds will have different impacts on consumers. For example, the cultural dimension includes individualism and collectivism. Comparing the cultural backgrounds of east Asians and Latin Americans, individualism and collectivism are more obvious among east Asians ( $\mathrm{Ng}, 2013)$. At the same time, this cultural background helps to solve the differences between participation behavior and information adoption behavior in social business (Chu \& Choi, 2011; Tsai \& Men, 2017). In the green consumer behavior model, face consciousness will promote the typical consumer green consumption behavior, thus the culture important regulating factor in social business, Chinese culture has a long history, under the influence of Confucian culture, face consciousness has become one of the indispensable factors influence consumer behavior. 


\section{Mll Macrothink}

International Journal of Human Resource Studies

ISSN 2162-3058

2020, Vol. 10, No. 1

Under the moderating effect of face consciousness, consumer information sharing can be regarded as the behavior of consumers to improve their own image in social software. In the online word-of-mouth communication of social media platforms, the initial communication is usually internet celebrity to introduce its own consumption experience, while the forwarding information belongs to the word-of-mouth communication of consumers. Because product characteristics are also an important factor in word of mouth communication, people tend to talk about new, well-known and visible products (Shi, Wu, \& Kuang, 2018). In social media, consumers share information and introduce a successful shopping experience, which is conducive to improving their self-image. Therefore, communicators are more willing to share their effective shopping experience due to the impact of Face consciousness (Berger \& Schwartz, 2011).

Besides, face consciousness can be identified as homogeneity to some extent. Homogeneity helps information flow. Due to common needs and product needs, the lower the perceived communication barrier between information source and receiver, the more important the similarity between information source and receiver is in belief identification (Pornpitakpan, 2004). Consumers regard symbolic information in internet celebrity's word-of-mouth as a unique attribute and transfer it to their own lives to construct their internal connection with symbolic information (Boon \& Lomore, 2001). Such self-construction behavior will make internet celebrity's word-of-mouth spokesmen form an inspiring image. Through purchase or information sharing, consumers can build satisfaction, trust, commitment, and other satisfaction in psychology (Elbeltagi \& Agag, 2016). Based on the moderating effect of face consciousness, consumers ascribe themselves to the ideal self. When the image of an internet celebrity word-of-mouth spokesperson is seen as consistent with their ideal self-image, consumers tend to follow celeb-approved attitudes and behaviors. When the individual conforms to the attitude or behavior advocated by the communicator, it will lead to identity identification, which leads to the satisfaction obtained by the individual in the belief (S. K. Kang \& Bodenhausen, 2015).

The following assumptions are made in this study:

H4a: Face consciousness will positively adjust the influence of consumer satisfaction on consumer information sharing

H4b: Face consciousness will positively regulate the influence of consumer trust on consumer information sharing

H4c: Face consciousness will positively modulate the impact of consumer commitment on consumer information sharing

\section{Research Methodology}

An extensive literature review was conducted in this study. The review focused on several related topics, such as information adoption models, internet celebrity word-of-mouth communication, relationship quality, face consciousness, and consumer information sharing. By reviewing the existing literature, this study analyzed and identified all problems related to internet celebrity word-of-mouth communication, relationship quality, face consciousness and 


\section{Macrothink}

International Journal of Human Resource Studies

ISSN 2162-3058 2020, Vol. 10, No. 1

consumer information sharing from the aspects of factors, theories, and methods. The delivery result of this approach is to determine the importance of internet celebrity word-of-mouth communication, relationship quality, face consciousness, and how it affects consumer information sharing.

\section{Conclusion and Limitations}

Social media is an important platform for consumers to express their own opinions (Makridakis, 2017). In social media platforms, ordinary people can also become spokespersons for focused information. Nowadays, consumer behavior is one of the important research topics in the field of marketing (Hussain et al., 2018).

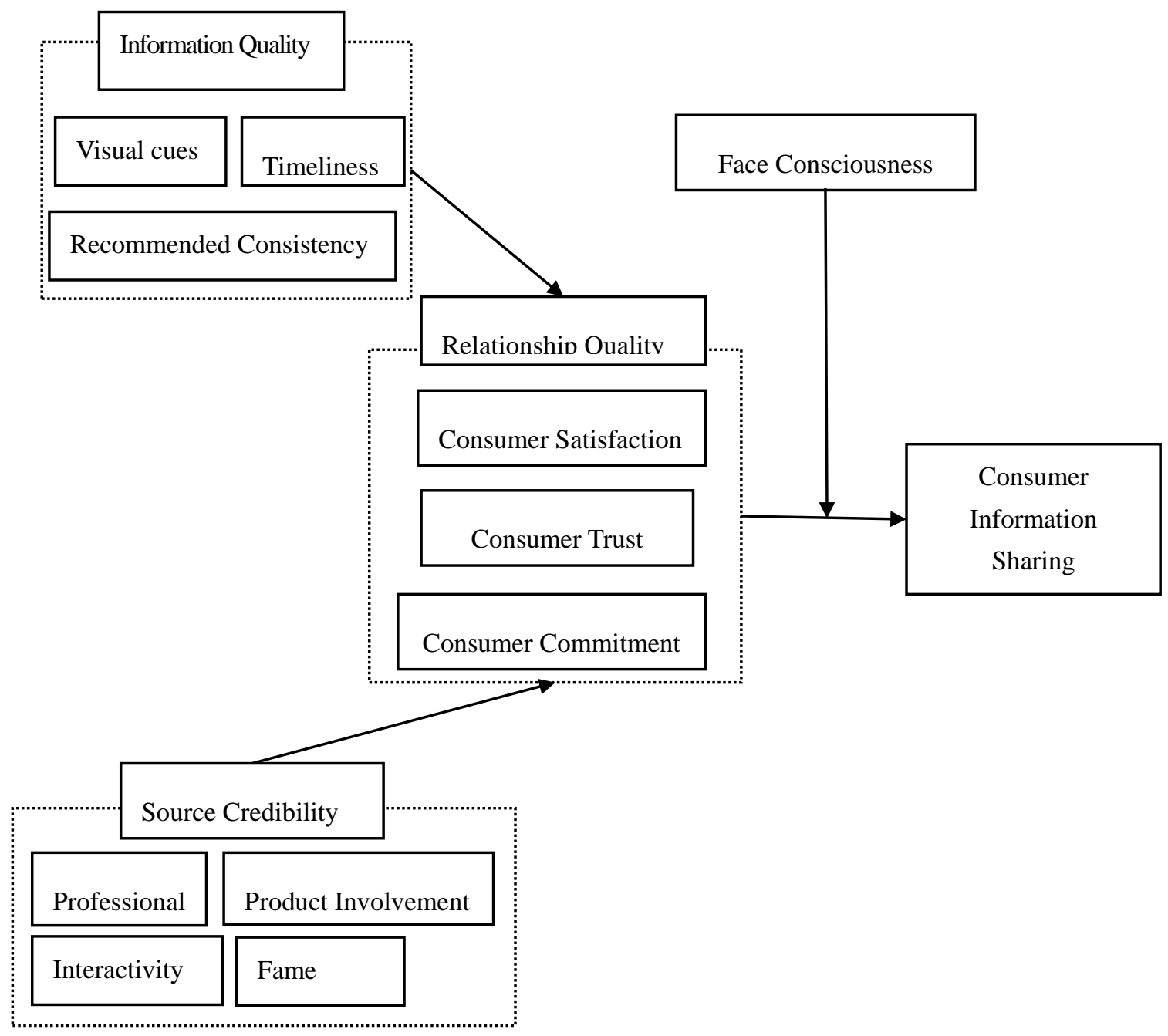

Figure 1. Research framework

Since the rise of social media, word-of-mouth communication has evolved from one-to-one communication to one-to-many and many-to-many communication (Sheth, 2018). Internet celebrity is an important factor in word-of-mouth communication, and its research on consumer information sharing has not been empirically tested. Given this, based on the 
information adoption model, this study establishes the influence model of consumer information sharing, studies internet celebrity word-of-mouth communication from the two aspects of internet celebrity information source characteristics and information quality, and elaborates the theoretical framework of internet celebrity word-of-mouth communication from its basic concepts, structural dimensions, relevant studies, and other aspects, hoping to further complement and extend the research on internet celebrity word-of-mouth communication.

Besides, this study integrates face consciousness into consumer behavior. As a cultural factor, the traditional Confucian culture has a profound impact on face consciousness. What choices consumers will make based on their motivation and self-efficacy when facing social media? This study focuses on the moderating effect of facial consciousness on consumers' information sharing. In previous studies, the research on face consciousness mainly focused on personality characteristics, and cultural factors were mainly used to explore the differences in pictures and text information displayed by users or consumers of different cultures in different countries, these studies did not explore the moderating role of face consciousness as a factor of Confucian traditional culture. This study takes face consciousness in Confucian traditional culture as a point to further discover the moderating role of the face in the influence of relationship quality on consumers' information sharing under the background of Confucianism.

At the same time, consumers' information-sharing behavior has gradually attracted the attention of enterprise marketers and academic researchers. It is expected that the results of this study can provide references and Suggestions for enterprises, marketing markets, and sales organizations.

Firstly, this study expects to find that internet celebrity can attract the common characteristics of fans, to help marketing companies to find the superior internet celebrity, by selecting internet celebrity characteristics, and creating competitive advantages through information flow to improve product promotion rate (Baabdullah, 2018).

Secondly, from the perspective of consumers, this study introduces relationship quality as a mediating variable to find out the impact of internet celebrity word-of-mouth communication on consumers. Relationship quality is "pro- internet celebrity" behavior. Consumers are willing to share information. Enterprises study different characteristics of consumers and seek to convert relationship quality into information-sharing behavior in social media. Consumer information sharing behavior on social media platforms is regarded as an important way for enterprises to obtain valuable data for analysis and prediction. Many enterprises establish close contact with customers through social media platforms and hope to get useful information feedback.

Thirdly, in Chinese cultural environment marketing, face consciousness is a typical representative of Chinese culture, the influence of Chinese culture cannot be ignored. Therefore, in this study, face consciousness is added to the relationship quality to consumer information sharing as a moderator, and the empirical results are expected to provide references for the marketing departments of enterprises. 
To sum up, this study is based on the information adoption model to explain how people are affected by information dissemination on social media platforms. In addition, in internet celebrity word-of-mouth communication under the social business environment, information adoption refers to the attitude or intention of information receivers to accept certain types of information, while consumer information sharing refers to the result of consumers' adoption of the information they receive. This study provides a comprehensive framework to explain the relationship between internet celebrity word-of-mouth communication, relationship quality, face consciousness, and consumer information sharing.

There are some limitations to this article. Firstly, since the proposed model needs to be further validated, this study will collect data from consumers concerned with internet celebrity dynamics to test the proposed model and further study the proposed hypothesis. Secondly, this study conceptualizes the information quality and information source characteristics of internet celebrity word-of-mouth communication. In addition, the sense of face is a special cultural awareness of Chinese consumers, which will have a great impact on consumer information sharing. Therefore, it is strongly recommended to collect questionnaires in different regions and enterprises to expand the sample diversity.

\section{Future Works}

As future work, based on this research model, according to the information adoption model, modify the model, further put forward a more complex research model, to better explain the relationship between internet celebrity word-of-mouth communication and consumer information sharing. Secondly, through interviews with internet celebrity representatives with high visibility and strong activity, questions that can reflect the information quality and information source characteristics of internet celebrity word-of-mouth communication can be obtained. Experts will then be invited to discuss and comment on selected measures to improve the validity of the content, and exploratory factor analysis will be used to construct the scale. Finally, the questionnaire was constructed with the internet celebrity word-of-mouth communication scales and the maturity scale adopted by other relevant variables, and the collected data were tested again through the questionnaire (Makridakis, 2017).

\section{References}

Abu Bakar, F. A., Zulkafly, N. Z., Rashad, M., Hanafie, M., \& Melan, M. (2017). Customer satisfaction towards AirAsia services among UUM student. http://repo.uum.edu.my/id/eprint/22608

Agnihotri, R., Dingus, R., Hu, M. Y., \& Krush, M. T. (2016). Social media: Influencing customer satisfaction in B2B sales. Industrial Marketing Management, 53, 172-180. http://dx.doi.org/10.1016/j.indmarman.2015.09.003

Ahmad, S. N., \& Laroche, M. (2017). Analyzing electronic word of mouth: A social commerce construct. International Journal of Information Management, 37(3), 202-213. http://dx.doi.org/10.1016/j.ijinfomgt.2016.08.004 
Alalwan, A. A., Dwivedi, Y. K., Rana, N. P., \& Williams, M. D. (2016). Consumer adoption of mobile banking in Jordan: examining the role of usefulness, ease of use, perceived risk and self-efficacy. Journal of Enterprise Information Management, 29(1), 118-139. http://dx.doi.org/10.1108/JEIM-04-2015-0035

Algharabat, R., Alalwan, A. A., Rana, N. P., \& Dwivedi, Y. K. (2017). Three dimensional product presentation quality antecedents and their consequences for online retailers: The moderating role of virtual product experience. Journal of Retailing Consumer Services, 36, 203-217. http://dx.doi.org/10.1016/j.jretconser.2017.02.007

Andaleeb, S. S., \& Anwar, S. F. (1996). Factors influencing customer trust in salespersons in a developing country. Journal of International Marketing, 4(4), 35-52. http://dx.doi.org/10.1177/1069031X9600400404

Baabdullah, A. M. (2018). Consumer adoption of Mobile Social Network Games (M-SNGs) in Saudi Arabia: The role of social influence, hedonic motivation and trust. Technology in Society, 53, 91-102. http://dx.doi.org/10.1016/j.techsoc.2018.01.004

Balabanis, G., \& Chatzopoulou, E. (2019). Under the influence of a blogger: The role of information-seeking goals and issue involvement. Psychology \& Marketing, 36(4), 342-353. http://dx.doi.org/10.1002/mar.21182

Belaid, S., \& Temessek Behi, A. (2011). The role of attachment in building consumer-brand relationships: an empirical investigation in the utilitarian consumption context. Journal of Product Brand Management, 20(1), 37-47. http://dx.doi.org/10.1108/10610421111108003

Berger, J., \& Schwartz, E. M. (2011). What drives immediate and ongoing word of mouth? Journal of Marketing Research, 48(5), 869-880. http://dx.doi.org/10.1509/jmkr.48.5.869

Bhattacherjee, A., Perols, J., \& Sanford, C. (2008). Information technology continuance: A theoretic extension and empirical test. Journal of Computer Information Systems, 49(1), 17-26. http://dx.doi.org/10.1080/08874417.2008.11645302

Boon, S. D., \& Lomore, C. D. (2001). Admirer-celebrity relationships among young adults: Explaining perceptions of celebrity influence on identity. Human communication research, 27(3), 432-465. http://dx.doi.org/10.1111/j.1468-2958.2001.tb00788.x

Boulianne, S. (2015). Social media use and participation: A meta-analysis of current research. Information, communication society Economy, 18(5), 524-538. http://dx.doi.org/10.1080/1369118X.2015.1008542

Bricci, L., Fragata, A., \& Antunes, J. (2016). The effects of trust, commitment and satisfaction on customer loyalty in the distribution sector. Journal of Economics, Business and Management, 4(2), 173-177. http://dx.doi.org/10.7763/JOEBM.2016.V4.386

Casaló, L., Flavián, C., \& Guinalíu, M. (2007). The impact of participation in virtual brand communities on consumer trust and loyalty: The case of free software. Online information review, 31(6), 775-792. http://dx.doi.org/10.1108/14684520710841766 


\section{Mll Macrothink}

International Journal of Human Resource Studies

ISSN 2162-3058 2020, Vol. 10, No. 1

Changliang, Z., Xiwei, W., \& Chenxiao, W. (2019). Research on Influencing Factors of Continuous Information Sharing Behavior of Users in Network Communities. Information Documentation Services, 40(3), 53-62. http://dx.doi.org/10.12154/j.qbzlgz.2019.03.009

Chen, H., \& Qi, Y. (2016). The Evaluation of Customer Satisfaction with the Third Party Logistics Service Quality for Online Shopping. Advances in Economics and Business, 4(5), 201-207. http://dx.doi.org/10.13189/aeb.2016.040501

Chen, J., Teng, L., Yu, Y., \& Yu, X. (2016). The effect of online information sources on purchase intentions between consumers with high and low susceptibility to informational influence. Journal of Business Research, 69(2), 467-475. http://dx.doi.org/10.1016/j.jbusres.2015.05.003

Chen, Y., Lu, Y., Wang, B., \& Pan, Z. (2019). How do product recommendations affect impulse buying? An empirical study on WeChat social commerce. Information \& Management, 56(2), 236-248. http://dx.doi.org/10.1016/j.im.2018.09.002

Cheung, C. M., Lee, M. K., \& Rabjohn, N. (2008). The impact of electronic word-of-mouth: The adoption of online opinions in online customer communities. Internet Research, 18(3), 229-247. http://dx.doi.org/10.1108/10662240810883290

Cho, M.-K., \& Kim, M. Y. (2017). Effects of learner motivation and teacher-student interaction on learner satisfaction in nursing students. The Journal of the Korea Contents Association, 17(4), 468-477. http://dx.doi.org/10.5392/JKCA.2017.17.04.468

Chu, S.-C., \& Choi, S. M. (2011). Electronic word-of-mouth in social networking sites: A cross-cultural study of the United States and China. Journal of Global Marketing, 24(3), 263-281. http://dx.doi.org/10.1080/08911762.2011.592461

Chu, S.-C., Windels, K., \& Kamal, S. (2016). The influence of self-construal and materialism on social media intensity: A study of China and the United States. International Journal of Advertising, 35(3), 569-588. http://dx.doi.org/10.1080/02650487.2015.1068425

Cooley, D., \& Parks-Yancy, R. (2019). The Effect of Social Media on Perceived Information Credibility and Decision Making. Journal of Internet Commerce, 1-21. http://dx.doi.org/10.1080/15332861.2019.1595362

Davis, F. D. (1989). Perceived usefulness, perceived ease of use, and user acceptance of information technology. MIS quarterly, 319-340. http://dx.doi.org/10.2307/249008

Dehghani, M., \& Tumer, M. (2015). A research on effectiveness of Facebook advertising on enhancing purchase intention of consumers. Computers in Human Behavior, 49, 597-600.

Djafarova, E., \& Rushworth, C. (2017). Exploring the credibility of online celebrities' Instagram profiles in influencing the purchase decisions of young female users. Computers in Human Behavior, 68, 1-7. http://dx.doi.org/10.1016/j.chb.2016.11.009 
Djafarova, E., \& Trofimenko, O. (2019). 'Instafamous'-credibility and self-presentation of micro-celebrities on social media. Information, Communication Society, 22(10), 1432-1446. http://dx.doi.org/10.1080/1369118X.2018.1438491

Domfeh, H. A., Kusi, L. Y., Nyarku, K. M., \& Ofori, H. (2018). The Mediating Effect of Customer Satisfaction in the Predictive Relation between Celebrity Advertising and Purchase Intentions in Telecom Industry in Ghana: University Students' Perspective. International Journal of Business and Management Invention (IJBMI), 7(3), 40-54. https://www.researchgate.net/publication/325070999

Dwivedi, A., \& Johnson, L. W. (2013). Trust-commitment as a mediator of the celebrity endorser-brand equity relationship in a service context. Australasian Marketing Journal (AMJ), 21(1), 36-42. http://dx.doi.org/10.1016/j.ausmj.2012.10.001

Elbeltagi, I., \& Agag, G. (2016). E-retailing ethics and its impact on customer satisfaction and repurchase intention: a cultural and commitment-trust theory perspective. Internet Research, 26(1), 288-310. http://dx.doi.org/10.1108/IntR-10-2014-0244

Ferns, B. H., \& Walls, A. (2012). Enduring travel involvement, destination brand equity, and travelers' visit intentions: A structural model analysis. Journal of Destination Marketing \& Management, 1(1-2), 27-35. http://dx.doi.org/10.1016/j.jdmm.2012.07.002

Goldsmith, R. E., Flynn, L. R., \& Goldsmith, E. B. (2003). Innovative consumers and market mavens. Journal of Marketing theory and practice, 11(4), 54-65. http://dx.doi.org/10.1080/10696679.2003.11658508

Goodrich, K., \& De Mooij, M. (2014). How 'social'are social media? A cross-cultural comparison of online and offline purchase decision influences. Journal of Marketing Communications, 20(1-2), 103-116. http://dx.doi.org/10.1080/13527266.2013.797773

Hajli, M. N. (2014a). Developing online health communities through digital media. International Journal of Information Management, 34(2), 311-314. http://dx.doi.org/10.1016/j.ijinfomgt.2014.01.006

Hajli, M. N. (2014b). The role of social support on relationship quality and social commerce. $\begin{array}{lllll}\text { Technological Forecasting } & \text { Social } & \text { Change, } & \text { 87, }\end{array}$ http://dx.doi.org/10.1016/j.techfore.2014.05.012

Hajli, M. N. (2014c). A study of the impact of social media on consumers. International Journal of Market Research, 56(3), 387-404. http://dx.doi.org/10.2501/IJMR-2014-025

Hajli, N., \& Sims, J. (2015). Social commerce: The transfer of power from sellers to buyers. Technological Forecasting Social Change, 94, 350-358. http://dx.doi.org/10.1016/j.techfore.2015.01.012

Hambrick, M. E., \& Mahoney, T. Q. (2011). 'It's incredible-trust me': exploring the role of celebrity athletes as marketers in online social networks. International Journal of Sport Management $\quad$ and 161-179. http://dx.doi.org/10.1504/IJSMM.2011.044794 
Hamid, A. A., Razak, F. Z. A., Bakar, A. A., \& Abdullah, W. S. W. (2016). The effects of perceived usefulness and perceived ease of use on continuance intention to use e-government. Procedia Economics

Finance,

35 ,

644-649. http://dx.doi.org/10.1016/S2212-5671(16)00079-4

Han, K.-H. (2016). The feeling of "face" in Confucian society: From a perspective of $\begin{array}{lllll}\text { psychosocial equilibrium. Frontiers in psychology, } & \text { 7, } & 1055 .\end{array}$ http://dx.doi.org/10.3389/fpsyg.2016.01055

Hennig-Thurau, T., Wiertz, C., \& Feldhaus, F. (2015). Does Twitter matter? The impact of microblogging word of mouth on consumers' adoption of new movies. Journal of the Academy of Marketing Science, 43(3), 375-394. http://dx.doi:10.1007/s11747-014-0388-3

Horzum, M. B. (2015). Interaction, Structure, Social Presence, and Satisfaction in Online Learning. Eurasia Journal of Mathematics, Science \& Technology Education, 11(3), 505-512. http://dx.doi: 10.12973/eurasia.2014.1324a

Hur, K., Kim, T. T., Karatepe, O. M., \& Lee, G. (2017). An exploration of the factors influencing social media continuance usage and information sharing intentions among Korean travellers. $\quad$ Tourism Management, $\quad 63, \quad$ 170-178. http://dx.doi.org/10.1016/j.tourman.2017.06.013

Hussain, S., Guangju, W., Jafar, R. M. S., Ilyas, Z., Mustafa, G., \& Jianzhou, Y. (2018). Consumers' online information adoption behavior: Motives and antecedents of electronic word of mouth communications. Computers in Human Behavior, 80, 22-32. http://dx.doi.org/10.1016/j.chb.2017.09.019

Iglesias, O., Markovic, S., \& Rialp, J. (2019). How does sensory brand experience influence brand equity? Considering the roles of customer satisfaction, customer affective commitment, and employee empathy. Journal of business research, 96, 343-354. http://dx.doi.org/10.1016/j.jbusres.2018.05.043

James, M. X., Hu, Z., \& Leonce, T. E. (2019). Predictors of organic tea purchase intentions by Chinese consumers: Attitudes, subjective norms and demographic factors. Journal of Agribusiness in Developing Emerging Economies, 9(3), 202-219. http://dx.doi.org/10.1108/JADEE-03-2018-0038

Kang, J.-W., \& Namkung, Y. (2019). The information quality and source credibility matter in customers' evaluation toward food $\mathrm{O} 2 \mathrm{O}$ commerce. International Journal of Hospitality Management, 78, 189-198. http://dx.doi.org/10.1016/j.ijhm.2018.10.011

Kang, J., Tang, L., \& Fiore, A. M. (2014). Enhancing consumer-brand relationships on restaurant Facebook fan pages: Maximizing consumer benefits and increasing active participation. International Journal of Hospitality Management, 36, 145-155. http://dx.doi.org/10.1016/j.ijhm.2013.08.015 
Kang, S. K., \& Bodenhausen, G. V. (2015). Multiple identities in social perception and interaction: Challenges and opportunities. Annual review of psychology, 66, 547-574. http://dx.doi.org/10.1146/annurev-psych-010814-015025

Kim, N., \& Kim, W. (2018). Do your social media lead you to make social deal purchases? Consumer-generated social referrals for sales via social commerce. International Journal of Information Management, 39, 38-48. http://dx.doi.org/10.1016/j.ijinfomgt.2017.10.006

Kim, S.-E., Lee, K. Y., Shin, S. I., \& Yang, S.-B. (2017). Effects of tourism information quality in social media on destination image formation: The case of Sina Weibo. Information Management, 54(6), 687-702. http://dx.doi.org/10.1016/j.im.2017.02.009

Kollat, J., \& Farache, F. (2017). Achieving consumer trust on Twitter via CSR communication. Journal of consumer marketing, 34(6), 505-514. http://dx.doi.org/10.1108/JCM-03-2017-2127

Lam, L. W., Chan, K. W., Fong, D., \& Lo, F. (2011). Does the look matter? The impact of casino servicescape on gaming customer satisfaction, intention to revisit, and desire to stay. International Journal of Hospitality Management, 30(3), 558-567. http://dx.doi.org/10.1016/j.ijhm.2010.10.003

Laumer, S., Maier, C., \& Weitzel, T. (2017). Information quality, user satisfaction, and the manifestation of workarounds: a qualitative and quantitative study of enterprise content management system users. European Journal of Information Systems, 26(4), 333-360. http://dx.doi.org/10.1057/s41303-016-0029-7. http://dx.doi.org/10.1108/MD-06-2017-0561

Lee, S., \& Choeh, J. Y. (2018). The interactive impact of online word-of-mouth and review helpfulness on box office revenue. Management Decision, 56(4), 849-866. http://dx.doi.org/10.1108/MD-06-2017-0561

Lee, W. O., \& Wong, L. S. (2016). Determinants of mobile commerce customer loyalty in Malaysia. Procedia-Social and Behavioral Sciences, 224, 60-67. http://dx.doi.org/10.1016/j.sbspro.2016.05.400

Li, J., Zhang, X.-A., \& Sun, G. (2015). Effects of "face" consciousness on status consumption among Chinese consumers: Perceived social value as a mediator. Psychological reports, 116(1), 280-291. http://dx.doi.org/10.2466/17.07.PR0.116k11w3

Lin, I. Y. (2009). The combined effect of color and music on customer satisfaction in hotel bars. Journal of Hospitality Marketing \& Management, 19(1), 22-37. http://dx.doi.org/10.1080/19368620903327675

Makridakis, S. (2017). The forthcoming Artificial Intelligence (AI) revolution: Its impact on society and firms. Futures, 90, 46-60. http://dx.doi.org/10.1016/j.futures.2017.03.006

Mohammadi, A., Saraee, M., \& Mirzaei, A. (2015). Time-sensitive influence maximization in social networks. Journal of Information Science, 41(6), 765-778. http://dx.doi.org/10.1177/0165551515602808 
Muralidharan, S., Rejón-Guardia, F., \& Xue, F. (2016). Understanding the green buying behavior of younger Millennials from India and the United States: A structural equation modeling approach. Journal of International Consumer Marketing, 28(1), 54-72. http://dx.doi.org/10.1080/08961530.2015.1056328

Nagy, A., Kemény, I., Szücs, K., Simon, J., \& Kiss, V. (2017). Are opinion leaders more satisfied? Results of a SEM model about the relationship between opinion leadership and online customer satisfaction. Society Economy, 39(1), 141-160. http://dx.doi.org/10.1556/204.2016.004

Namkung, Y., \& Jang, S. (2008). Are highly satisfied restaurant customers really different? A quality perception perspective. International Journal of Contemporary Hospitality Management, 20(2), 142-155. http://dx.doi.org/10.1108/09596110810852131

Ng, C. S.-P. (2013). Intention to purchase on social commerce websites across cultures: A cross-regional study. Information management, 50(8), 609-620. http://dx.doi.org/10.1016/j.im.2013.08.002

Ngai, E. W., Tao, S. S., \& Moon, K. K. (2015). Social media research: Theories, constructs, and conceptual frameworks. International Journal of Information Management, 35(1), 33-44. http://dx.doi.org/10.1016/j.ijinfomgt.2014.09.004

Nguyen, N.-T., \& Tran, T.-T. (2018). Strategies in Building Brand Loyalty Based on Consumers' Experience, Trust and Satisfaction: A Study in Vietnamese Using Smartphone Context. Journal of Informatics and Mathematical Sciences, 10(4), 583-598. http://dx.doi.org/10.26713\%2Fjims.v10i4.1051

Noori, A. S., Hashim, K. F., \& Yusof, S. A. M. (2016). The Conceptual Relation of Electronic Word-of-mouth, Commitment and Trust in Influencing Continuous Usage of Social Commerce. International Review of Management and Marketing, 6(7S), 226-230. https://dergipark.org.tr/tr/pub/irmm/issue/32101/355648

Park, J. H., Gu, B., Leung, A. C. M., \& Konana, P. (2014). An investigation of information sharing and seeking behaviors in online investment communities. Computers in Human Behavior, 31, 1-12. http://dx.doi.org/10.1016/j.chb.2013.10.002

Pentina, I., Zhang, L., \& Basmanova, O. (2013). Antecedents and consequences of trust in a social media brand: A cross-cultural study of Twitter. Computers in Human Behavior, 29(4), 1546-1555. http://dx.doi.org/10.1016/j.chb.2013.01.045

Petty, R. E., Cacioppo, J. T., \& Goldman, R. (1981). Personal involvement as a determinant of argument-based persuasion. Journal of personality social psychology, 41(5), 847. http://dx.doi.org/10.1037/0022-3514.41.5.847

Pitta, D. A., \& Fowler, D. (2005). Online consumer communities and their value to new product developers. Journal of Product Brand Management, 14(5), 283-291. http://dx.doi.org/10.1108/10610420510616313 
Pornpitakpan, C. (2004). The persuasiveness of source credibility: A critical review of five decades' evidence. Journal of applied social psychology, 34(2), 243-281. http://dx.doi.org/10.1111/j.1559-1816.2004.tb02547.x

Prendergast, G., Paliwal, A., \& Chan, K. K. F. (2018). Trust in online recommendations: An evolutionary psychology perspective. International Journal of Advertising, 37(2), 199-216. http://dx.doi.org/10.1080/02650487.2016.1239879

Rajput, N., \& Talan, A. (2017). Impact of Impulsive Buying Behavior and Opinion Leadership on the Relationship between Emotional Intelligence and Consumer Satisfaction of Smartphone buyers. Global Journal of Enterprise Information System, 9(3). http://dx.doi:10.18311/gjeis/2017/15731

Roudposhti, V. M., Nilashi, M., Mardani, A., Streimikiene, D., Samad, S., \& Ibrahim, O. (2018). A new model for customer purchase intention in e-commerce recommendation agents. Journal of International Studies, $11(4), \quad 237-253$. http://dx.doi:10.14254/2071-8330.2018/11-4/17

Saleem, F. (2017). The Impact of Celebrity Endorsement on Brand Affection and Purchase Intention: The Mediating Role of Word of Mouth. http://dx.doi.org/10.35536/ljb.2017.v5.i2.a3

Sari, D. M. F. P., \& Yulianti, N. M. D. R. (2019). Celebrity endorsement, electronic word of mouth and trust brand on buying habits. International journal of social sciences humanities, 3(1), 82-90. http://dx.doi.org/10.29332/ijssh.v3n1.261

Sebastianelli, R., \& Tamimi, N. (2018). E-tailer website attributes and trust: understanding the role of online reviews. Online Information Review, 42(4), 506-519. http://dx.doi.org/10.1108/OIR-02-2016-0039

Shen, X. L., Cheung, C. M., \& Lee, M. K. (2013). What leads students to adopt information from W ikipedia? An empirical investigation into the role of trust and information usefulness. British Journal of Educational Technology, 44(3), 502-517. http://dx.doi.org/10.1111/j.1467-8535.2012.01335.x

Sheth, J. N. (2018). How social media will impact marketing media. In Social media marketing (pp. 3-18): Springer. http://dx.doi.org/10.1007/978-981-10-5323-8_1

Shi, Z., Wu, L., \& Kuang, Z. (2018). How face consciousness reverse pro-self-behavior? A study on ecological consumption from the perspective of social value orientation. Journal of $\begin{array}{llll}\text { Contemporary } \quad \text { Marketing } & \text { Science, } & 1(1), & 117-144 .\end{array}$ http://dx.doi.org/10.1108/JCMARS-07-2018-0004

Shu, M., \& Scott, N. (2014). Influence of social media on Chinese students' choice of an overseas study destination: An information adoption model perspective. Journal of Travel Tourism Marketing, 31(2), 286-302. http://dx.doi.org/10.1080/10548408.2014.873318 
Simmonds, G., \& Spence, C. (2017). Thinking inside the box: How seeing products on, or through, the packaging influences consumer perceptions and purchase behaviour. Food Quality Preference, 62, 340-351. http://dx.doi.org/10.1016/j.foodqual.2016.11.010

Su, L., Swanson, S. R., Chinchanachokchai, S., Hsu, M. K., \& Chen, X. (2016). Reputation and intentions: The role of satisfaction, identification, and commitment. Journal of business research, 69(9), 3261-3269. http://dx.doi.org/10.1016/j.jbusres.2016.02.023

Sussman, S. W., \& Siegal, W. S. (2003). Informational influence in organizations: An integrated approach to knowledge adoption. Information systems research, 14(1), 47-65. http://dx.doi.org/10.1287/isre.14.1.47.14767

Swani, K., Milne, G. R., Brown, B. P., Assaf, A. G., \& Donthu, N. (2017). What messages to post? Evaluating the popularity of social media communications in business versus consumer $\begin{array}{llll}\text { markets. Industrial } \quad \text { Marketing } & \text { Management, }\end{array}$ http://dx.doi.org/10.1016/j.indmarman.2016.07.006

Tabrani, M., Amin, M., \& Nizam, A. (2018). Trust, commitment, customer intimacy and customer loyalty in islamic banking relationships. International Journal Of Bank Marketing, 36(5), 823-848. http://dx.doi.org/10.1108/IJBM-03-2017-0054

Teng, S., Khong, K. W., Chong, A. Y. L., \& Lin, B. (2017). Persuasive electronic word-of-mouth messages in social media. Journal of Computer Information Systems, 57(1), 76-88. http://dx.doi.org/10.1080/08874417.2016.1181501

Tien, D. H., Rivas, A. A. A., \& Liao, Y.-K. (2019). Examining the influence of customer-to-customer electronic word-of-mouth on purchase intention in social networking $\begin{array}{llll}\text { sites. Asia Pacific } \quad \text { Management 238-249. } & \text { Review, }\end{array}$ http://dx.doi.org/10.1016/j.apmrv.2018.06.003

Tsai, W.-H. S., \& Men, L. R. (2017). Consumer engagement with brands on social network sites: A cross-cultural comparison of China and the USA. Journal of Marketing Communications, 23(1), 2-21. http://dx.doi.org/10.1080/13527266.2014.942678

Wang, J.-C., \& Chang, C.-H. (2013). How online social ties and product-related risks influence purchase intentions: A Facebook experiment. Electronic Commerce Research Applications, 12(5), 337-346. http://dx.doi.org/10.1016/j.elerap.2013.03.003

Wang, L., Wei, F., \& Zhang, X.-a. (2018). Why Does Energy-Saving Behavior Rise and Fall? A Study on Consumer Face Consciousness in the Chinese Context. Journal of Business Ethics, 1-15. http://dx.doi.org/10.1007/s10551-018-3944-9

Wei, J., \& Meng, F. (2016). Can Opinion Leaders Influence the Purchase Intention of Online Consumer. International Journal of u-and e-Service, Science and Technology, 9(1), 373-384. http://dx.doi.org/10.14257/ijunesst.2016.9.1.38

Yan, X., Wang, J., \& Chau, M. (2015). Customer revisit intention to restaurants: Evidence from online reviews. Information Systems Frontiers, 17(3), 645-657. http://dx.doi:10.1007/s10796-013-9446-5 


\section{Macrothink}

International Journal of Human Resource Studies

ISSN 2162-3058 2020, Vol. 10, No. 1

Zeng, B., \& Gerritsen, R. (2014). What do we know about social media in tourism? A review. Tourism management perspectives, 10, 27-36. http://dx.doi.org/10.1016/j.tmp.2014.01.001

Zhang, K. Z., \& Benyoucef, M. (2016). Consumer behavior in social commerce: A literature review. Decision Support Systems, 86, 95-108. http://dx.doi.org/10.1016/j.dss.2016.04.001

\section{Copyright Disclaimer}

Copyright for this article is retained by the author(s), with first publication rights granted to the journal.

This is an open-access article distributed under the terms and conditions of the Creative Commons Attribution license (http://creativecommons.org/licenses/by/4.0/). 